\title{
EMPLOYMENT POLICY IN THE EUROPEAN UNION
}

Marina KESNER-ŠKREB, MSc

Glossary*

Institute of Public Finance, Zagreb

Important principles, objectives and activities of the employment policy of the Union include promotion of a high level of employment throughout the Community by developing a coordinated strategy, particularly with regard to the creation of a skilled, trained and adaptable workforce and labour markets responsive to economic change.

The Union's responsibilities with regard to employment are complementary to those of the member states, the main aim being to create a European Employment Strategy (EES). The EES is intended as the main instrument to provide direction and to coordinate the employment policy priorities supported by member states at a European level.

\section{Towards a more comprehensive employment policy}

1 The White Paper on Growth, Competitiveness and Employment (1993)

The high level of unemployment in most EU countries contributed to the release of the White Paper on Growth, Com- petitiveness and Employment. It launched the debate on the European economic and employment strategy by bringing the issue of employment to the top of the European agenda for the first time.

\section{The Essen Process (1994)}

In order to fight unemployment, the European Council of Essen in December 1994 agreed on five key objectives to be pursued by member states: (1) to invest in vocational training, (2) increase employment by intensive growth, (3) reduce non-wage labour costs, (4) increase active labour market policies, and (5) fight youth and longterm unemployment. Member states were charged with translating these recommendations into multi-annual programmes monitored by the Commission and the Council. The European Council was informed annually on the result of the Commission's and the Council's review. The Essen Process helped to raise awareness of the high unemployment in the member states at EU level.

\footnotetext{
* Received: August 31, 2010

Accepted: September 2, 2010
} 
3 The contribution of the Amsterdam Treaty (1997)

The new Employment Title in the Amsterdam Treaty set up the European Employment Strategy and the permanent, Treaty-based Employment Committee with advisory status to promote coordination of the member states' employment and labour market policies.

The Treaty has not changed the basic principle of the member states having the sole competence for employment policy but the member states have committed themselves to co-ordinating their employment policies at Community level. The Treaty entrusts the Council and the Commission with a much stronger role and with new tasks and tools. The European Parliament has been brought more closely into the decision making process, too. The responsibilities of social partners and their abilities to contribute are also enhanced through the inclusion of the Social Protocol into the Treaty.

\section{The European Employment Strategy 1997-2004}

The extraordinary Luxembourg Job Summit in November 1997 anticipated the entry into force of the Amsterdam Treaty in 1998 and launched the European Employment Strategy, the so-called Luxembourg Process.

It created the framework for the annual cycle for coordinating and monitoring national employment policies. The coordination of national employment policies at EU level is based on the commitment of the member states to establishing a set of common objectives and targets. The strategy was built around the following components:

- Employment guidelines: based on a proposal from the Commission, the Council agreed every year on a seri- es of guidelines setting out common priorities for member states' employment policies;

- National action plans: each member state drew up an annual national action plan describing how these guidelines are implemented in practice at the national level;

- Joint Employment Report: the Commission and the Council jointly examined the national action plans and presented a joint employment report to the European Council. Based on this analysis, the Commission presented a proposal for the employment guidelines for the following year;

- Recommendations: the Council may decide, by a qualified majority, to issue country-specific recommendations upon a proposal by the Commission.

In 2000, the Lisbon European Council agreed on the new strategic goal of making the EU "the most competitive and dynamic knowledge-based economy in the world", capable of sustaining economic growth with more and better jobs and greater social cohesion. It embraced full employment as an overarching objective of employment and social policy and set concrete targets to be achieved in 2010, i.e. increase the overall employment rate to $70 \%$ and the women's employment rate to more than $60 \%$. In 2001 , another target was added to raise the employment rate for older workers (55 to 64 years) to $50 \%$ by 2010 .

To reflect these conclusions, five new "horizontal objectives" were introduced in the 2001 guidelines: realising full employment, stimulating lifelong learning, promoting the role of social partners, ensuring a proper policy mix between the four pillars, and developing common indicators in order to assess progress. The improvement of the quality in work was added in 2002. 
The Employment Guidelines 2005-2008 and 2008-2010

The Integrated Guidelines 2005-2008 and 2008-2010 contain a total of 23 guidelines, of which 8 are devoted specifically to employment to boost the Lisbon strategy. The eight employment guidelines are essential to reach the three priorities for action in the field of employment (1) attract and retain more people in employment, increase labour supply and modernise social protection systems, (2) improve adaptability of workers and enterprises, (3) increase investment in human capital through better education and skills. The main target is to increase the employment rate to $70 \%$ by 2010 .

\section{LITERATURE}

EnterEurope [online]. Available from: [http://www.entereurope.hr/page. aspx?PageID=106].

Europa - Gateway to the European Union [online]. Available from: [http://europa.eu/pol/socio/index_en.htm].

European Parliament. Fact Sheets on the European Union [online]. Available from: [http://www.europarl.europa.eu/ parliament/expert/displayFtu.do?language $=$ en $\& \mathrm{id}=74 \& \mathrm{ftuId}=$ FTU_4.9.3.html].

Glossary [online]. Available from: [http://europa.eu/scadplus/glossary/index_ en.htm]. 